\title{
PRVIH POLA STOLJEĆA HRVATSKOGA KNJIŽNIČARSKOG DRUŠTVA KAO NAKLADNIKA KNJIGA NIZOVI, GLAVNI UREDNICI I UREDNIČKI ODBORI
}

\author{
THE FIRST HALF-CENTURY OF THE CROATIAN \\ LIBRARY ASSOCIATION AS A BOOK PUBLISHER: \\ SERIES, EDITORS IN CHIEF AND EDITORIAL BOARDS
}

\section{Ivana Hebrang Grgić}

Odsjek za informacijske i komunikacijske znanosti

Filozofski fakultet Sveučilišta u Zagrebu

ihgrgic@ffzg.hr

UDK / UDC 070.4(091)HKD

Pregledni rad / Review

Prihvaćeno / Accepted: 23. 4. 2017.

\section{Sažetak}

Provedeno je istraživanje kako bi se dao pregled nizova, glavnih urednika i uredničkih odbora nizova knjiga koje je Hrvatsko knjižničarsko društvo objavilo od 1966. do 2016. godine. Analizirane su promjene naziva nizova, promjene glavnih urednika i uredničkih odbora te korištena terminologija u izvještajima glavnih urednika i u drugim dokumentima HKD-a. Cilj je rada raščistiti terminološke nedoumice, prikazati profiliranje nizova te napraviti popis svih članova uredničkih odbora i glavnih urednika po godinama i nizovima koje su uređivali. Podaci su prikupljeni izravnim uvidom u podatke objavljene u publikacijama te analizom sadržaja skupštinskih izvještaja glavnih urednika i drugih dokumenata. Na temelju rezultata zaključuje se o ulozi i važnosti nakladničke djelatnosti Hrvatskog knjižničarskog društva te se daju prijedlozi izmjena u uredničkoj i nakladničkoj praksi.

Ključne riječi: Hrvatsko knjižničarsko društvo, nizovi, urednici, urednički odbor, nakladnička djelatnost

Vjesnik bibliotekara Hrvatske 60, 1(2017), 1-22

ISSN 0507-1925

(C) VBH 2017. 


\section{Summary}

The paper gives an overview of series, editors in chief and editorial boards of all the series published by the Croatian Library Association from 1966 to 2016. Changes of book serial titles are analyzed, as well as names of editors in chief and members of editorial boards. Terminology used in the editors' annual reports and other Association's documents is also analyzed. The aim of the paper is to clarify the terminological dilemmas and inconsistencies, present the development and profiling of the series, and create a list of all members of the editorial boards and editors in chief with the corresponding data on the periods and series they served as editors. The data were collected using the method of content analysis of the editors' annual reports and other Association's documents, and analyzing the data printed in the books. Based on the results, conclusions have been made about the role and importance of publishing activities of the Croatian Library Association and some suggestions have been offered for the future changes in editorial and publishing practices.

Keywords: Croatian Library Association, book series, editors in chief, editorial board, publishing activity

\section{Uvod}

Iako Hrvatsko knjižničarsko društvo (HKD) počinje objavljivati knjige 1966. godine kada je objavljena publikacija Abecedni katalog u teoriji i praksi Eve Verone, treba spomenuti da je još 1962. godine objavljen (u suradnji sa Savezom društava bibliotekara Jugoslavije koje je navedeno kao nakladnik) prvi od četiri snopića nacrta Pravilnika za izradbu abecednih kataloga Eve Verone. Bio je to nacrt umnožen strojopisom i svrha je bila da se o njemu raspravlja. ${ }^{1}$ Taj je nacrt objavljen u četiri snopića (1962., 1963., 1965. i 1967.), a tek je na četvrtom kao nakladnik navedeno tadašnje Društvo bibliotekara Hrvatske. Prema tome, razvidno je da se u HKD-u i prije 1966. godine razmišljalo o važnosti objavljivanja stručnih knjiga i priručnika, a o njihovu će se nedostatku izvještavati i u kasnijim izvješćima uredničkih odbora.

Godine 1968. pokrenuta su dva niza - Izdanja Društva bibliotekara Hrvatske i Posebna izdanja Društva bibliotekara Hrvatske, a u izvještaju o izdavačkoj djelatnosti po prvi se put spominju imena članova uredničkog odbora - Aleksandar Stipčević (glavni urednik), Branko Tomečak, Anica Molnar i Mate Šikić (tehnički urednik). ${ }^{2}$ Od tada pa sve do 2003. godine svi će nizovi imati zajednički urednički

\footnotetext{
1 Mišić, Jelka. O izdavačkoj djelatnosti Društva bibliotekara Hrvatske. // Vjesnik bibliotekara Hrvatske 3/4(1968), str. 252-255.

2 Mišić, Jelka. Društvo bibliotekara Hrvatske od svibnja 1967. do svibnja 1969. : (prema tajničkom izvještaju podnesenom XVII. godišnjoj skupštini). // Vjesnik bibliotekara Hrvatske 1/2(1969), str. 31.
} 
odbor i zajedničkog glavnog urednika. Do kraja 2016. godine objavljeno je 149 knjiga u izdanju HKD-a.

\section{Metodologija i cilj istraživanja}

Cilj je istraživanja detaljno istražiti povijest objavljivanja knjiga u Hrvatskome knjižničarskom društvu, proučiti profiliranje pojedinih nizova te izraditi popise glavnih urednika nizova i članova uredničkih odbora. Prikupljani su podaci o nazivima nizova, glavnim urednicima nizova, članovima uredničkih odbora, ISSN-oznakama nizova, podaci o sadržaju i načinu uređivanja publikacija unutar nizova te eventualni zapisi o razlozima pokretanja pojedinih nizova. Istraživanje je provedeno u tri faze. U prvoj su pregledani i zabilježeni podaci sa samih publikacija (s preliminarnih stranica). Budući da je uočeno kako podaci na publikacijama nisu uvijek vjerodostojni (na nekim publikacijama navodili su se raniji urednici ako je publikacija pripremljena u prethodnom mandatnom razdoblju ili su se kao članovi uredničkih odbora navodili članovi programskih odbora ako se radilo o zbornicima radova), u drugoj fazi istraživanja pregledani su zapisnici (izvještaji) s redovnih skupština Hrvatskoga knjižničarskog društva. U slučaju da u zapisnicima nisu pronađeni precizniji podaci, pregledavali su se zapisnici sa sastanaka Glavnih odbora. Osim navedenih dokumenata, pregledani su i statuti HKD-a radi usporedbe terminologije vezane uz nakladničku djelatnost. U trećoj su fazi za publikacije za koje su postojale nedoumice provjereni zapisi u katalogu Nacionalne i sveučilišne knjižnice u Zagrebu (NSK).

\section{Pokretanje nizova, nazivi i identifikatori}

Prve dvije publikacije koje je objavio HKD (objavljene 1966. i 1967.) objavljene su izvan nizova. Današnji niz Izdanja HKD-a pokrenut je 1968., kao i niz koji danas ima naslov Posebna izdanja HKD-a. Niz s današnjim naslovom Povremena izdanja HKD-a izlazi od 1978. (od 1995. pojavljuje se i kolo unutar tog niza - Povremena izdanja HKD-a, Novi niz), a niz Elektronička izdanja HKD-a izlazi od 2007. godine. ${ }^{3}$ Iako je prva knjiga u nizu Hrvatsko knjižničarstvo objavljena 2012. godine, niz je pokrenut 2011. godine kada je i započeo rad na uređivanju prvog rukopisa. ${ }^{4}$ Unutar niza Izdanja HKD-a 2014. godine pokrenuto je kolo Slobodan pristup informacijama.

\footnotetext{
3 Barbarić, Ana. Prijevodi IFLA-inih dokumenata u izdanju Hrvatskoga knjižničarskog društva : analiza, stanje, perspektiva. // Libellarium 7, 2(2014), str. 197-230.

4 Hrvatsko knjižničarsko društvo. Zapisnik sa 6., elektroničke sjednice Glavnog odbora HKD-a. 3. i 4. svibnja 2011. [citirano: 2016-10-28]. Dostupno na http://hkdrustvo.hr/hr/dokumenti/kategorija/zapisnici_glavnog_odbora_2010/.
} 
Naziv društva mijenjan je u dva navrata, a budući da je naziv društva bio sastavni dio naslova svakog niza, nizovi su mijenjali naslove ovisno o promjeni naziva društva. Naziv društva u početku je nakladničke djelatnosti bio Društvo bibliotekara Hrvatske (DBH), 1971. godine promijenjen je u Hrvatsko bibliotekarsko društvo (HBD), a 1998. godine u Hrvatsko knjižničarsko društvo (HKD). Bez obzira na promjene stvarnih naslova nizova, publikacije su kontinuirano numerirane (tablica 1). Zbog toga ćemo dalje nizove promatrati kao cjeline, bez obzira na promjenu naziva društva koja je utjecala i na promjenu naslova nizova, a radi jednostavnosti koristit ćemo današnje naslove nizova. ISSN-oznake nisu zatražene za svaki niz. Prema podacima na publikacijama, unutar nizova pokrenuta su i dva kola - Novi niz u nizu Povremena izdanja HKD-a te Slobodan pristup informacijama u nizu Izdanja HKD-a. Tablica 1 izrađena je na temelju uvida u publikacije.

Tablica 1. Nizovi koje objavljuje HKD (prema podacima na publikacijama)

\begin{tabular}{|c|c|c|c|}
\hline $\begin{array}{l}\text { Naslov niza } \\
\text { Naslov kola }\end{array}$ & $\begin{array}{l}\text { Godina } \\
\text { pokretanja }\end{array}$ & $\begin{array}{l}\text { Numeracija } \\
\text { publikacija }\end{array}$ & ISSN \\
\hline Izdanja Društva bibliotekara Hrvatske & 1968. & Knjige 1-4 & - \\
\hline $\begin{array}{l}\text { Izdanja Hrvatskoga bibliotekarskog } \\
\text { društva }\end{array}$ & 1971. & Knjige 5-26 & $0419-9278$ \\
\hline $\begin{array}{l}\text { Izdanja Hrvatskoga knjižničarskog } \\
\text { društva }\end{array}$ & 1998. & Knjige 27-65 & $1846-5544$ \\
\hline Slobodan pristup informacijama & 2014. & Knjiga 63-65 & $1849-5109$ \\
\hline $\begin{array}{l}\text { Posebna izdanja Društva bibliotekara } \\
\text { Hrvatske }\end{array}$ & 1968. & Knjige 1-2 & - \\
\hline $\begin{array}{l}\text { Posebna izdanja Hrvatskoga } \\
\text { bibliotekarskog društva }\end{array}$ & 1975. & Knjige 3-7 & - \\
\hline $\begin{array}{l}\text { Posebna izdanja Hrvatskoga } \\
\text { knjižničarskog društva }\end{array}$ & 2000. & Knjige 8-14 & - \\
\hline $\begin{array}{l}\text { Povremena izdanja Hrvatskoga } \\
\text { bibliotekarskog društva }\end{array}$ & 1978. & Knjige 1-10 & $1334-7896$ \\
\hline $\begin{array}{l}\text { Povremena izdanja Hrvatskoga } \\
\text { bibliotekarskog društva. Novi niz }\end{array}$ & 1995. & Knjiga 1 & $1334-7675$ \\
\hline $\begin{array}{l}\text { Povremena izdanja Hrvatskoga } \\
\text { knjižničarskog društva. Novi niz }\end{array}$ & 1999. & Knjiga 2-32 & $1334-7667$ \\
\hline $\begin{array}{l}\text { Povremena izdanja Hrvatskoga } \\
\text { knjižničarskog društva }\end{array}$ & 2003. & Knjiga 11 & - \\
\hline $\begin{array}{l}\text { Elektronička izdanja Hrvatskoga } \\
\text { knjižničarskog društva }\end{array}$ & 2007. & Knjige 1-6 & $1846-5447$ \\
\hline Niz Hrvatsko knjižničarstvo & 2012. & Knjige 1-2 & $1848-493 X$ \\
\hline
\end{tabular}


Do kraja 2016. godine u nizu Izdanja HKD-a objavljeno je 65 publikacija, u nizu Posebna izdanja HKD-a objavljeno je 14 publikacija, u nizu Povremena izdanja HKD-a 43 publikacije, u nizu Elektronička izdanja HKD-a 6 publikacija, a u nizu Hrvatsko knjižničarstvo 2 publikacije. Izvan nizova objavljeno je 19 publikacija. Grafikon 1. pokazuje ukupan broj knjiga objavljenih po godinama.

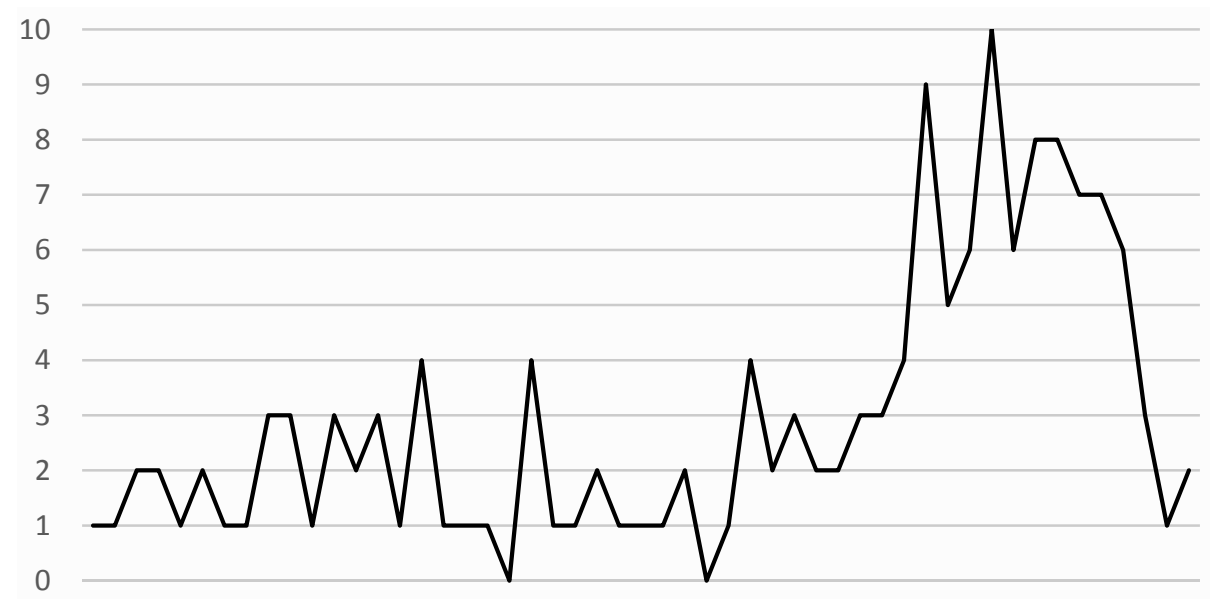

66.68. 70.72.74.76.78. 80. 82. 84. 86. 88. 90.92.94.96.98.00.02.04.06.08.10.12.14.16.

Grafikon 1. Broj objavljenih knjiga u izdanju HKD-a od 1966. do kraja 2016. godine

\section{Terminološke nedosljednosti}

Jasno je iz prikazanoga da Hrvatsko knjižničarsko društvo ima dugu tradiciju objavljivanja knjiga - prije pola stoljeća prepoznata je važnost objavljivanja stručnih i znanstvenih knjiga na hrvatskome jeziku i to je zasigurno imalo pozitivan utjecaj na profiliranje i razvoj hrvatskoga knjižničarstva. Postoje međutim neke terminološke nedosljednosti vezane uz nazive nizova, numeraciju i godišnje izvještaje. Te su nedosljednosti istražene i prikazuju se u ovome radu kako bi se stvorio temelj za promišljanja o budućnosti nakladničke djelatnosti HKD-a.

Prvo što može biti zbunjujuće u nazivima nizova jest upravo njihova spomenuta promjena ovisno o promjeni naziva društva. U vrijeme promjena naziva društva, svi nizovi imali su naziv izdavača kao dio naslova niza. Drugi razlog zbog kojeg su čak i urednici i članovi tijela HKD-a ponekad griješili jest ponavljanje sintagme „izdanja HKD-a“ u nazivima četiriju nizova, a to je ujedno i potpuni naziv jednoga 
od nizova. Ta sintagma zapravo je generički pojam koji se u dokumentima HKD-a često koristi u čak četiri različita značenja:

1. niz Izdanja HKD-a (ispravan naslov niza pisan velikim početnim slovom)

2. svi nizovi knjiga koje objavljuje HKD (izdanja HKD-a, pisano malim početnim slovom $)^{5}$

3. sva izdanja koja objavljuje HKD (a osim nizova knjiga, to su i Vjesnik bibliotekara Hrvatske i HKD Novosti) ${ }^{6}$

4. sva izdanja koja objavljuje HKD, uključujući i mrežne stranice i Facebook-stranicu HKD-a. ${ }^{7}$

Pregledavajući brojne skupštinske i godišnje izvještaje, moguće je pronaći i drugačiju terminologiju. Primjerice ponekad se nizovi knjiga koje objavljuje HKD nazivaju društvenim izdanjima (pa i Društvenim izdanjima, velikim početnim slovom). ${ }^{8}$ U nekim se pak izvještajima piše o nizu Društvena izdanja HBD-a, a misli se zapravo na niz Izdanja HBD-a. ${ }^{9}$

Sama uredništva, tj. urednički odbori, u izvještajima sebe nazivaju različito (prenosimo i početna slova kako su navedena u izvještajima): urednički odbor (1969.), ${ }^{10}$ Uredništvo društvenih izdanja (1977./78.), ${ }^{11}$ urednički odbor društvenih izdanja ili uređivački odbor (1987.), ${ }^{12}$ uredništvo Društvenih izdanja (1994.), ${ }^{13}$ Urednički odbor izdanja HBD-a (1996.). ${ }^{14}$

Pogrešaka koje ukazuju da je neujednačena terminologija unosila zabunu ima i u izvještajima nakon 2000. godine. Primjerice u izvještaju za niz Povremena izda-

5 Npr. Hrvatsko knjižničarsko društvo. Zapisnik sa 6. sjednice Glavnog odbora HKD-a održane 19. prosinca 2005. [citirano: 2016-10-28]. Dostupno na http://hkdrustvo.hr/datoteke/155.

6 Npr. Hrvatsko knjižničarsko društvo. Statut. 2015., čl. 58 [citirano: 2016-10-29]. Dostupno na http://hkdrustvo.hr/hr/statut/.

7 Npr. Hrvatsko knjižničarsko društvo. O nama : organizacija [citirano: 2016-10-10]. Dostupno na http://hkdrustvo.hr/hr/o nama/.

8 Malim slovom npr. u Stipčević, Aleksandar. Izvještaj Uredništva društvenih izdanja od 1975.-1977. godine. // Vjesnik bibliotekara Hrvatske 23, 1/4(1977/78), str. 111; velikim slovom npr. u: Nebesny, Tatjana. Izvještaj uredništva Društvenih izdanja. // Vjesnik bibliotekara Hrvatske 37, 3/4(1994), str. 147.

9 Gomerčić, Nada. Izvještaj glavnog urednika Društvenih izdanja Hrvatskoga bibliotekarskog društva. // Vjesnik bibliotekara Hrvatske 32, 1/4(1989), str. 193.

10 Mišić, Jelka. Društvo. Nav. dj. Str. 31.

11 Stipčević, Aleksandar. Nav. dj. Str. 111.

12 Gomerčić, Nada. Izvještaj uredničkog odbora društvenih izdanja. // Vjesnik bibliotekara Hrvatske 30, 1/4(1987), str. 190 .

13 Nebesny, Tatjana. Nav. dj. Str. 147.

14 Nebesny, Tatjana. Izvještaj o radu uredničkog odbora izdanja HBD-a : 1994.-1996. // Vjesnik bibliotekara Hrvatske 39, 3/4(1996), str. 97. 
nja HKD-a 2004. godine ${ }^{15}$ uredništvo se naziva uredništvom Izdanja HKD-a iako se misli na sva izdanja, a ne na niz Izdanja HKD-a (isto je primjerice i 2008., ${ }^{16}$ $2010 .{ }^{17}$ i $\left.2013 .{ }^{18}\right)$. Iste te godine, 2004., u izvještaju za niz Izdanja HKD-a uredništvo se naziva i uredništvom Izdanja HKD-a, i uredničkim odborom Izdanja HKD-a, i Uredničkim odborom Društvenih izdanja. ${ }^{19}$

Promatraju li se statuti HKD-a, jasno je da se i u njima različito nazivaju i opisuju nizovi koje Društvo objavljuje. U statutu iz 1986. godine doslovno se navode naslovi nizova: „Društvo izdaje stalne nizove publikacija: Izdanja Hrvatskoga bibliotekarskog društva i Posebna izdanja Hrvatskoga bibliotekarskog društva koje uređuje Urednički odbor" ${ }^{20}$ Zanimljivo je da se ne spominje niz Povremena izdanja Hrvatskoga bibliotekarskog društva u kojem je do tada već objavljeno šest knjiga (dobiva se dojam da je formulacija jednostavno preuzeta iz ranijih statuta bez dodavanja naslova novoga niza). U statutu iz 1992. nema bitnih izmjena, i u njemu se navode samo dva niza spomenuta u ranijoj verziji statuta. ${ }^{21} \mathrm{U}$ statutu iz 1999. godine dolazi do promjena - više se ne navode stvarni naslovi nizova, već u statutu piše: „Društvo izdaje stalna, povremena i prigodna izdanja, koja uređuju Urednički odbori izdanja“. ${ }^{22}$ Zahvaljujući takvoj formulaciji, u slučaju promjene stvarnih naslova nizova neće biti potrebno mijenjati statut. ${ }^{23}$ Ista je formulacija i u Statutu HKD-a usvojenu u siječnju 2002. godine. ${ }^{24}$ Statut iz 2015. godine donosi izmjene jer se uvodi Odbor za nakladničku djelatnost. U čl. 58 se kao članovi

15 Wiler, Mirna. Izvještaj o radu uredničkog odbora Izdanja Hrvatskoga knjižničarskog društva za niz Povremena izdanja HKD-a : 2003. -2004. // Vjesnik bibliotekara Hrvatske 47, 3/4(2004), str. 162.

16 Willer, Mirna. Izvještaj o radu uredničkog odbora Izdanja Hrvatskoga knjižničarskog društva za niz Povremena izdanja HKD-a. Novi niz : 2006.-2008. // Vjesnik bibliotekara Hrvatske 51, 1/4(2008), str. 229.

17 Barbarić, Ana. Izvještaj o radu uredničkog odbora Izdanja Hrvatskoga knjižničarskog društva za niz Povremena izdanja HKD-a. Novi niz : rujan 2008.-rujan 2010. // Vjesnik bibliotekara Hrvatske 53, 3/4(2010), str. 222.

18 Hebrang Grgić, Ivana. Izvješće glavne urednice niza Hrvatsko knjižničarstvo Hrvatskoga knjižničarskog društva. // Vjesnik bibliotekara Hrvatske 56, 1/2(2013), str. 349.

19 Gjurković Govorčin, Rajka. Izvještaj o radu uredničkog odbora Izdanja Hrvatskoga knjižničarskog društva za niz Izdanja HKD-a : 2002.-2004. // Vjesnik bibliotekara Hrvatske. 47, 3/4(2004), str. 159.

20 Statut Hrvatskoga bibliotekarskog društva. // Vjesnik bibliotekara Hrvatske 29, 1/4(1986), str. 183-195, čl. 26.

${ }_{21}$ Statut Hrvatskoga bibliotekarskog društva. // Vjesnik bibliotekara Hrvatske 35, 3/4(1992), str. 237-250, čl. 26.

22 Statut Hrvatskoga knjižničarskog društva. // Vjesnik bibliotekara Hrvatske 42, 1/4(1999), str. 179-166, čl. 37.

23 Barbarić, Ana. Prijevodi. Nav. dj.

24 Statut Hrvatskoga knjižničarskog društva. // Vjesnik bibliotekara Hrvatske 45, 3/4(2002), str. 307-321. Čl. 60. 
Odbora spominju ,urednici stalnih izdanja Društva“"25 pri čemu se pod izdanjima misli i na VBH i HKD Novosti, ali i na mrežne i Facebook-stranice HKD-a (to i nije sasvim jasno iz samog teksta Statuta, ali na stranicama HKD-a su kao članovi Odbora za nakladničku djelatnost navedeni i urednici VBH, HKD Novosti te mrežnih i Facebook-stranica ${ }^{26}$ ). U Statutu iz 2015. godine za urednički se odbor koristi i alternativni termin (uredništvo).

Svakako valja spomenuti nesporazume koji su povezani sa sastavom uredničkih odbora. Do 2003. godine svi su nizovi imali istog glavnog urednika i isti urednički odbor. Budući da je u to vrijeme važio statut $\mathrm{u}$ kojem se urednički odbori spominju u množini (statut iz 2002. ${ }^{27}$, ali množina je i u statutu iz 1999., kao i u trenutno važećem statutu dostupnom na mrežnim stranicama Društva $\left.{ }^{28}\right)$, to bi značilo da svaki urednik može odabrati članove uredničkog odbora svoga niza koji mogu biti različiti od članova uredničkih odbora drugih nizova. Međutim u praksi je do sada uvijek djelovao zajednički urednički odbor u kojem su bili glavni urednici nizova uz još ponekog člana koji nije glavni urednik nijednoga niza, ali je bio u uredničkom odboru svih nizova. Prema tome, iako postoji mogućnost osnivanja više uredničkih odbora, njihov je sastav jednak, pa se i o uredničkim odborima često piše u jednini. ${ }^{29}$

Analizom terminologije na mrežnim stranicama Hrvatskoga knjižničarskog društva postaje jasno da i tamo postoje nedoumice, nejasnoće i nedosljednosti. U listopadu 2016. godine na stranici koja nosi naslov Izdanja navedene su tri kategorije: Društvena izdanja (gdje je nabrojeno šest nizova knjiga), Vjesnik bibliotekara Hrvatske i HKD Novosti. Prema tome, Društvena izdanja navedena su kao potkategorija Izdanja, a u ranijim su dokumentima, kao što je prikazano, izrazi izdanja i društvena izdanja često bili istoznačnice. Na poveznici Online narudžba izdanja ${ }^{30}$ zapravo se pod izdanjima naručuje ono što se na istoj mrežnoj stranici naziva društvenim izdanjima (samo knjige, ne VBH ni HKD Novosti). Kada se pak daje popis uredničkih odbora, oni se nazivaju uredništvima HKD-ovih izdanja, a potkategorije su Uredništvo VBH, Uredništvo HKD Novosti, Uredništvo Društvenih izdanja te Uredništvo mrežnih stranica HKD-a (ovdje su navedeni podaci o uredniku i uredništvu mrežnih stranica, ali i podatak o uredniku Face-

\footnotetext{
25 Hrvatsko knjižničarsko društvo. Statut. 2015. Nav. dj.

26 Hrvatsko knjižničarsko društvo. O nama : organizacija [citirano: 2016-10-10]. Dostupno na http://hkdrustvo.hr/hr/o_nama/.

27 Statut Hrvatskoga knjižničarskog društva. // Vjesnik bibliotekara Hrvatske 45, 3/4(2002). Čl. 60.

28 Hrvatsko knjižničarsko društvo. Statut. 2015. Čl. 41. Nav. dj.

29 Npr. Willer, Mirna. Izvještaj o radu uredničkog odbora Izdanja Hrvatskog knjižničarskog društva za niz Povremena izdanja HKD-a. Novi niz : 2006.-2008. Nav. dj. Str. 229.

30 Hrvatsko knjižničarsko društvo. Društvena izdanja : narudžba [citirano: 2016-10-28]. Dostupno na http://hkdrustvo.hr/izdanja/drustvena.
} 
book-stranice). ${ }^{31}$ Prema tome, neki termini koji su naizgled istoznačnice (izdanja, društvena izdanja, HKD-ova izdanja) na mrežnim stranicama HKD-a koriste se s različitim i neujednačenim, pa stoga i nejasnim značenjima.

Na mrežnim stranicama postoji i bibliografija svih knjiga objavljenih u izdanju HKD-a. U toj bibliografiji ima pogrešaka koje nisu terminološke, već su vezane uz numeraciju knjiga. Knjige su numerirane arapskim brojkama od 1 (prva publikacija iz 1966.) do 148 (posljednja publikacija objavljena 2016.) Međutim na popisu je zapravo 150 jedinica, iako je objavljeno 149 knjiga. Jedna publikacija nije numerirana (između jedinica pod brojevima 95 i 96), a dvije su publikacije označene istim brojem (133). ${ }^{32}$ Treba spomenuti i problem publikacije koja objavljuje radove sa seminara Arhivi, knjižnice, muzeji. Ta publikacija izlazila je kao zbornik radova, ali je od 2014. godine dostupna i na internetu kao AKM časopis (brojevi 17 i 18). ${ }^{33}$ Broj 19 (za 2016. godinu) objavljen je samo u tiskanom obliku i ni na jednom mjestu ne spominje naslov AKM časopis. Na stranicama Hrvatskoga knjižničarskog društva naveden je u popisu knjiga (pod brojem 146). Na tiskanom primjerku nije navedena ISBN-oznaka, a radovi su pojedinačno recenzirani i kategorizirani (što nije običaj u omeđenim publikacijama), pa je prema tome on ipak serijska publikacija. Na taj se način dolazi do brojke od 149 objavljenih knjiga.

Još jedna terminološka nejasnoća koju valja spomenuti javlja se u vezi s knjigama koje su sve do 2010. povremeno objavljivane izvan nizova. Objavljeno ih je ukupno 19, a taj je niz često kolokvijalno nazivan Nenumeriranim nizom (velikim početnim slovom) ${ }^{34}$ a ponekad i nenumeriranim nizom (malim početnim slovom). ${ }^{35}$ Iako nikada nije službeno tako nazvan i iako se taj naslov ne spominje ni na jednoj publikaciji, Nenumerirani niz je 2011. godine preimenovan u niz $\mathrm{Hr}-$ vatsko knjižničarstvo. Pri pokretanju niza Hrvatsko knjižničarstvo dogodila se još jedna pogreška koja je proizašla iz ranije navedenih terminoloških nedosljednosti - niz Hrvatsko knjižničarstvo registriran je pri ISSN-uredu za Hrvatsku s vrlo zbunjujućim stvarnim naslovom: Izdanja Hrvatskoga knjižničarskog društva, Niz Hrvatsko knjižničarstvo. Na temelju planova i izvještaja jasno je da se ovdje ne

\footnotetext{
31 Hrvatsko knjižničarsko društvo. O nama. Nav. dj.

32 Hrvatsko knjižničarsko društvo. Društvena izdanja [citirano: 2016-10-28]. Dostupno na http:// hkdrustvo.hr/hr/izdanja/kategorija/drustvena/.

33 AKM časopis [citirano: 2016-12-11]. Dostupno na http://hrcak.srce.hr/ojs/index.php/akm/index.

34 Hrvatsko knjižničarsko društvo. Zapisnik sa 6., elektroničke sjednice Glavnog odbora HKD-a. 3. i 4. svibnja 2011. [citirano: 2016-10-28]. Dostupno na http://hkdrustvo.hr/hr/dokumenti/kategorija/zapisnici_glavnog_odbora_2010/.

35 Nebesny, Tatjana. Bibliografija izdanja Hrvatskoga knjižničarskog društva : 1940.-2000. // Hrvatsko knjižničarsko društvo : 14. III. 1940. - 14. III. 2000. : spomenica / uredile Živković, Daniela ; Horvat, Aleksandra ; Malnar, Aleksandra. Zagreb : Hrvatsko knjižničarsko društvo, 2000. Str. 41-55.
} 
radi o kolu unutar niza Izdanja Hrvatskoga knjižničarskog društva, već o potpuno novom nizu izdanja Hrvatskoga knjižničarskog društva - Hrvatsko knjižničarstvo.

Potencijalno zbunjujuća može biti i numeracija knjiga u onome što HKD smatra kolom Slobodan pristup informacijama niza Izdanja HKD-a. Naime u tome je kolu nastavljena numeracija niza (knjige 63, 64 i 65 do kraja 2016.), a nije istaknuta numeracija kola. U razdoblju kada su objavljene prve tri knjige kola, nije objavljena nijedna druga knjiga u nizu. Kada međutim bude objavljena još poneka knjiga, numeracija knjiga u kolu Slobodan pristup informacijama bit će isprekidana (npr. moguće stanje na kraju 2017.: u kolu Slobodan pristup informacijama bit će objavljene knjige 63,64, 65 i 67, jer će kao 66. knjiga biti numeriran neki drugi zbornik koji će, možda, biti objavljen između knjige 65 i 67). Također je vrlo zbunjujuće i nije sasvim jasno je li Slobodan pristup informacijama kolo niza Izdanja HKD-a ili je zapravo riječ o serijskoj publikaciji. Uvidom u publikacije jasno je da izdavač (HKD) Slobodan pristup informacijama smatra kolom - knjige su uređene kao omeđene publikacije (npr. navedeni su naslovi i ISSN-oznake niza i kola, a recenzija je rađena na razini cijele publikacije, što je praksa u knjigama, a ne u serijskim publikacijama). Ipak, u publikacijama se ne navodi ISBN-oznaka (prema naputku ISSN-ureda). Također, uvidom u katalog NSK jasno je da se publikacija do 2013. godine obrađuje kao knjiga, a nakon toga kao serijska publikacija. Prema tome, ISSN-ured i NSK Slobodan pristup informacijama smatraju serijskom publikacijom, dok izdavač smatra da je to omeđena publikacija i na taj ju način uređuje.

Navedimo još dvije uočene nedosljednosti. Godine 2007. imenovana je nova glavna urednica niza Posebna izdanja HKD-a, a uz naziv niza u zagradi stoji napomena da je riječ o nizu koji objavljuje zbornike. ${ }^{36}$ Očito je da je to bila zabuna jer su se zbornici već tada objavljivali u nizu Izdanja HKD-a. Još jedna pogreška učinjena je kada je u Vjesniku bibliotekara Hrvatske objavljen izvještaj za razdoblje 2012.-2014. za niz Izdanja HKD-a. Osim što su navedeni pogrešni podaci o objavljenim publikacijama i suradnicima, u potpisu stoji ime osobe koja nije nikada bila urednik niti član uredničkog odbora bilo kojeg niza. ${ }^{37}$

\section{Glavni urednici i članovi uredničkih odbora nizova knjiga}

Do kraja 2002. godine sva izdanja imala su zajedničkog glavnog urednika i urednički odbor (svi nizovi, kao i knjige objavljene izvan nizova). Krajem 2002. godine dugogodišnji članovi uredničkog odbora podnijeli su ostavke - glavna

\footnotetext{
36 Hrvatsko knjižničarsko društvo. Zapisnik s 2. sjednice Glavnog odbora Hrvatskoga knjižničarskog društva održane 15. prosinca 2006. [citirano: 2016-11-02]. Dostupno na http://hkdrustvo. $\mathrm{hr} /$ datoteke/259.

37 Špiranec, Sonja (i. e. Špac, Vesna). Izvještaj glavne urednice niza Izdanja Hrvatskoga knjižničarskog društva. // Vjesnik bibliotekara Hrvatske 58, 1/2(2015), str. 404-406.
} 
urednica Tatjana Nebesny te članovi Đurđa Zorko i Aleksandar Stipčević. Od 2003. postoje dva glavna urednika - Rajka Gjurković Govorčin za Izdanja HKD-a i Mirna Willer za Povremena izdanja - dok su ostali članovi uredništva Aleksandra Horvat, Daniela Živković i Marjana Janeš Žulj. U zapisniku se ne spominje ime glavnog urednika niza Posebna izdanja HKD-a. ${ }^{38}$ Dana 19. lipnja 2006. godine Glavni je odbor prihvatio da svaki niz ima svoga urednika. ${ }^{39}$

U nastavku donosimo popis svih članova uredničkih odbora s posebno izdvojenim glavnim urednicima. Podaci su prikupljeni uvidom u skupštinske izvještaje objavljene u VBH-u, uvidom u zapisnike sa zasjedanja glavnih odbora te uvidom u same publikacije. Kod sastavljanja popisa prednost se davala zapisnicima i izvještajima jer podaci u samim publikacijama nisu uvijek potpuni. Mate Šikić u nekim je izvještajima navođen kao član uredničkog odbora (uz naznaku da je tehnički urednik), a u nekima nije. Na publikacijama je navođen odvojeno od popisa članova uredničkog odbora, kao tehnički urednik. Budući da je njegova uloga uvijek bila ista (tehnički urednik), $\mathrm{u}$ tablicama nije naveden u popisima članova uredničkih odbora, ali vrijedi spomenuti da je ulogu tehničkoga urednika obnašao od 1968. do 2000. godine. Tablica 1. prikazuje popis glavnih urednika i članova uredničkog odbora od 1968. do 2003. godine. Budući da od 2003. godine nizovi mogu imati različite glavne urednike, od te se godine popisi navode posebno za svaki niz - za niz Izdanja HKD-a u tablici 2., za niz Posebna izdanja HKD-a u tablici 3., za niz Povremena izdanja HKD-a u tablici 4., za niz Elektronička izdanja HKD-a u tablici 5., a za niz Hrvatsko knjižničarstvo u tablici 6.

Tablica 1. Popis glavnih urednika i članova uredničkih odbora od 1968. do 2003. godine

\begin{tabular}{|l|l|l|}
\hline Godine & Glavni urednik & Urednički odbor \\
\hline 1968.-1975. & Aleksandar Stipčević & Anica Molnar, Branko Tomečak \\
\hline 1975.-1977. & Aleksandar Stipčević & $\begin{array}{l}\text { Lidija Abramović, Vanda Ekl, Mira } \\
\text { Mikačić, Branko Tomečak }\end{array}$ \\
\hline 1977.-1978. & Aleksandar Stipčević & $\begin{array}{l}\text { Lidija Abramović, Vanda Ekl, Mira } \\
\text { Mikačić }\end{array}$ \\
\hline 1979. & Aleksandar Stipčević & $\begin{array}{l}\text { Nada Gomerčić, Branko Hanž, Ljerka } \\
\text { Markić Čučuković, Mira Mikačić }\end{array}$ \\
\hline
\end{tabular}

38 Hrvatsko knjižničarsko društvo. Zapisnik sa 4. sjednice Glavnog odbora HKD-a održane 24. siječnja 2003. [citirano: 2016-11-02]. Dostupno na http://hkdrustvo.hr/datoteke/23.

39 Hrvatsko knjižničarsko društvo. Zapisnik s 11. sjednice Glavnog odbora HKD-a održane 19. lipnja 2006. [citirano: 2016-10-28]. Dostupno na http://hkdrustvo.hr/datoteke/210. 


\begin{tabular}{|l|l|l|}
\hline Godine & Glavni urednik & Urednički odbor \\
\hline 1980. & Aleksandar Stipčević & $\begin{array}{l}\text { Lidija Abramović, Vanda Ekl, Mira } \\
\text { Mikačić, Branko Tomečak }\end{array}$ \\
\hline 1981.-1983. & Aleksandar Stipčević & $\begin{array}{l}\text { Nada Gomerčić, Branko Hanž, Ljerka } \\
\text { Markić-Čučuković, Mira Mikačić }\end{array}$ \\
\hline 1983.-1989. & Nada Gomerčić & $\begin{array}{l}\text { Ljerka Markić-Čučuković, Mira Mikačić, } \\
\text { Vera Mudri-Škunca, Dora Sečić, } \\
\text { Aleksandar Stipčević }\end{array}$ \\
\hline 1989.-1992. & Aleksandra Horvat & $\begin{array}{l}\text { Tatjana Nebesny, Aleksandar Stipčević, } \\
\text { Daniela Živković }\end{array}$ \\
\hline 1992.-2003. & Tatjana Nebesny & $\begin{array}{l}\text { Aleksandra Horvat, Aleksandar } \\
\text { Stipčević, Đurđa Zorko, Daniela } \\
\text { Živković }\end{array}$ \\
\hline
\end{tabular}

Tablica 2. Popis glavnih urednika i članova uredničkih odbora niza Izdanja Hrvatskoga knjižničarskog društva od 2003. godine.

\begin{tabular}{|l|l|l|}
\hline Godine & Glavni urednik & Urednički odbor \\
\hline 2003.-2005. & $\begin{array}{l}\text { Rajka Gjurković- } \\
\text { Govorčin }\end{array}$ & $\begin{array}{l}\text { Aleksandra Horvat, Marjana Janeš-Žulj, } \\
\text { Mirna Willer, Daniela Živković }\end{array}$ \\
\hline 2006.-2007. & $\begin{array}{l}\text { Rajka Gjurković- } \\
\text { Govorčin }\end{array}$ & $\begin{array}{l}\text { Aleksandra Horvat, Marjana Janeš-Žulj, } \\
\text { Ivana Zenić, Mirna Willer, Daniela Živković }\end{array}$ \\
\hline 2007.-2008. & $\begin{array}{l}\text { Ivana Marinković } \\
\text { Zenić }\end{array}$ & $\begin{array}{l}\text { Rajka Gjurković-Govorčin, Aleksandra } \\
\text { Horvat, Marjana Janeš-Žulj, Mirna Willer, } \\
\text { Daniela Živković }\end{array}$ \\
\hline 2008.-2009. & Irena Kranjec & $\begin{array}{l}\text { Rajka Gjurković-Govorčin, Aleksandra } \\
\text { Horvat, Lobel Machala, Daniela Živković }\end{array}$ \\
\hline 2009.-2010. & Irena Kranjec & $\begin{array}{l}\text { Ana Barbarić, Rajka Gjurković-Govorčin, } \\
\text { Aleksandra Horvat, Lobel Machala, Breza } \\
\text { Salamon-Cindori, Daniela Živković }\end{array}$ \\
\hline 2010.-2011. & Irena Kranjec & $\begin{array}{l}\text { Ana Barbarić, Rajka Gjurković-Govorčin, } \\
\text { Ivana Hebrang Grgić, Lobel Machala, Breza } \\
\text { Šalamon-Cindori, Daniela Živković }\end{array}$ \\
\hline 2011.-2012. & Irena Kranjec & $\begin{array}{l}\text { Ana Barbarić, Ivana Hebrang Grgić, Lobel } \\
\text { Machala, Breza Šalamon-Cindori, Daniela } \\
\text { Živković }\end{array}$ \\
\hline
\end{tabular}




\begin{tabular}{|l|l|l|}
\hline Godine & Glavni urednik & Urednički odbor \\
\hline 2012.-2014. & Vesna Špac & $\begin{array}{l}\text { Ivana Hebrang Grgić, Lobel Machala, Dina } \\
\text { Mašina, Ivana Pažur }\end{array}$ \\
\hline 2014.-2016. & Tihomir Marojević & $\begin{array}{l}\text { Ivana Hebrang Grgić, Dina Mašina, Lobel } \\
\text { Machala, Davorka Pšenica }\end{array}$ \\
\hline
\end{tabular}

Tablica 3. Popis glavnih urednika i članova uredničkih odbora niza Posebna izdanja Hrvatskoga knjižničarskog društva od 2005. godine

\begin{tabular}{|l|l|l|}
\hline Godine & Glavni urednik & Urednički odbor \\
\hline 2005.-2006. & $\begin{array}{l}\text { Rajka Gjurković- } \\
\text { Govorčin }\end{array}$ & $\begin{array}{l}\text { Aleksandra Horvat, Marjana Janeš-Žulj, } \\
\text { Mirna Willer, Daniela Živković }\end{array}$ \\
\hline 2006.-2008. & $\begin{array}{l}\text { Rajka Gjurković- } \\
\text { Govorčin }\end{array}$ & $\begin{array}{l}\text { Aleksandra Horvat, Marjana Janeš-Žulj, } \\
\text { Ivana (Marinković) Zenić, Mirna Willer, } \\
\text { Daniela Živković }\end{array}$ \\
\hline 2009.-2010. & $\begin{array}{l}\text { Rajka Gjurković- } \\
\text { Govorčin }\end{array}$ & $\begin{array}{l}\text { Ana Barbarić, Aleksandra Horvat, Irena } \\
\text { Kranjec, Lobel Machala, Daniela Živković }\end{array}$ \\
\hline $2010 .-2011$. & $\begin{array}{l}\text { Rajka Gjurković- } \\
\text { Govorčin }\end{array}$ & $\begin{array}{l}\text { Ana Barbarić, Ivana Hebrang Grgić, Irena } \\
\text { Kranjec, Lobel Machala, Breza Salamon- } \\
\text { Cindori, Daniela Živković }\end{array}$ \\
\hline $2011 .-2012$. & Lobel Machala & $\begin{array}{l}\text { Ana Barbarić, Ivana Hebrang Grgić, Irena } \\
\text { Kranjec, Breza Šalamon-Cindori, Daniela } \\
\text { Živković }\end{array}$ \\
\hline $2012 .-2014$. & Lobel Machala & $\begin{array}{l}\text { Dina Mašina, Ivana Hebrang Grgić, Ivana } \\
\text { Pažur, Vesna Špac }\end{array}$ \\
\hline $2014 .-2016$. & Lobel Machala & $\begin{array}{l}\text { Tihomir Marojević, Ivana Hebrang Grgić, } \\
\text { Dina Mašina, Davorka Pšenica }\end{array}$ \\
\hline
\end{tabular}

Tablica 4. Popis glavnih urednika i članova uredničkih odbora niza Povremena izdanja Hrvatskoga knjižničarskog društva (Novi niz) od 2003. godine

\begin{tabular}{|l|l|l|}
\hline Godine & Glavni urednik & Urednički odbor \\
\hline 2003.-2006. & Mirna Willer & $\begin{array}{l}\text { Rajka Gjurković-Govorčin, Aleksandra } \\
\text { Horvat, Marjana Janeš-Žulj, Daniela } \\
\text { Živković }\end{array}$ \\
\hline
\end{tabular}




\begin{tabular}{|l|l|l|}
\hline Godine & Glavni urednik & Urednički odbor \\
\hline 2006.-2007. & Mirna Willer & $\begin{array}{l}\text { Rajka Gjurković-Govorčin, Aleksandra } \\
\text { Horvat, Marjana Janeš-Žulj, Ivana } \\
\text { Marinković Zenić, Daniela Živković }\end{array}$ \\
\hline 2007.-2008. & Mirna Willer & $\begin{array}{l}\text { Rajka Gjurković-Govorčin, Aleksandra } \\
\text { Horvat, Ivana Marinković Zenić, Daniela } \\
\text { Živković }\end{array}$ \\
\hline 2008.-2010. & Ana Barbarić & $\begin{array}{l}\text { Rajka Gjurković-Govorčin, Aleksandra } \\
\text { Horvat, Irena Kranjec, Lobel Machala, } \\
\text { Breza Šlamon-Cindori, Daniela Živković }\end{array}$ \\
\hline 2010.-2011. & Ana Barbarić & $\begin{array}{l}\text { Rajka Gjurković-Govorčin, Ivana Hebrang } \\
\text { Grgić, Irena Kranjec, Lobel Machala, Breza } \\
\text { Šalamon-Cindori, Daniela Živković }\end{array}$ \\
\hline 2011.-2012. & Ana Barbarić & $\begin{array}{l}\text { Ivana Hebrang Grgić, Irena Kranjec, Lobel } \\
\text { Machala, Breza Šalamon-Cindori, Daniela } \\
\text { Živković }\end{array}$ \\
\hline 2012.-2014. & Dina Mašina & $\begin{array}{l}\text { Ivana Hebrang Grgić, Lobel Machala, Ivana } \\
\text { Pažur, Vesna Špac }\end{array}$ \\
\hline 2014.-2016. & Dina Mašina & $\begin{array}{l}\text { Ivana Hebrang Grgić, Lobel Machala, } \\
\text { Tihomir Marojević, Davorka Pšenica }\end{array}$ \\
\hline
\end{tabular}

Tablica 5. Popis glavnih urednika i članova uredničkih odbora niza Elektronička izdanja Hrvatskoga knjižničarskog društva od pokretanja 2007. godine

\begin{tabular}{|l|l|l|}
\hline Godine & Glavni urednik & Urednički odbor \\
\hline 2007. & Mirna Willer & $\begin{array}{l}\text { Rajka Gjurković-Govorčin, Aleksandra } \\
\text { Horvat, Marjana Janeš-Žulj, Ivana } \\
\text { Marinković Zenić, Daniela Živković }\end{array}$ \\
\hline 2008. & Mirna Willer & $\begin{array}{l}\text { Rajka Gjurković-Govorčin, Aleksandra } \\
\text { Horvat, Daniela Živković }\end{array}$ \\
\hline 2010.-2011. & Ana Barbarić & $\begin{array}{l}\text { Rajka Gjurković-Govorčin, Ivana Hebrang } \\
\text { Grgić, Irena Kranjec, Lobel Machala, Breza } \\
\text { Šalamon-Cindori, Daniela Živković }\end{array}$ \\
\hline 2011.-2012. & Ana Barbarić & $\begin{array}{l}\text { Ivana Hebrang Grgić, Irena Kranjec, Lobel } \\
\text { Machala, Breza Šalamon-Cindori, Daniela } \\
\text { Živković }\end{array}$ \\
\hline
\end{tabular}




\begin{tabular}{|l|l|l|}
\hline Godine & Glavni urednik & Urednički odbor \\
\hline 2012.-2014. & Ivana Pažur & $\begin{array}{l}\text { Dina Mašina, Ivana Hebrang Grgić, Lobel } \\
\text { Machala, Vesna Špac }\end{array}$ \\
\hline 2014.-2016. & Dina Mašina & $\begin{array}{l}\text { Tihomir Marojević, Ivana Hebrang Grgić, } \\
\text { Lobel Machala, Davorka Pšenica }\end{array}$ \\
\hline
\end{tabular}

Tablica 6. Popis glavnih urednika i članova uredničkih odbora niza Hrvatsko knjižničarstvo od pokretanja 2011. godine

\begin{tabular}{|l|l|l|}
\hline Godine & Glavni urednik & Urednički odbor \\
\hline $2011 .-2012$. & $\begin{array}{l}\text { Ivana Hebrang } \\
\text { Grgić }\end{array}$ & $\begin{array}{l}\text { Ana Barbarić, Irena Kranjec, Lobel } \\
\text { Machala, Breza Šalamon-Cindori, Daniela } \\
\text { Živković }\end{array}$ \\
\hline 2012.-2014. & $\begin{array}{l}\text { Ivana Hebrang } \\
\text { Grgić }\end{array}$ & $\begin{array}{l}\text { Lobel Machala, Dina Mašina, Ivana Pažur, } \\
\text { Vesna Špac }\end{array}$ \\
\hline 2014.-2016. & Davorka P̌senica & $\begin{array}{l}\text { Ivana Hebrang Grgić, Lobel Machala, } \\
\text { Tihomir Marojević, Dina Mašina }\end{array}$ \\
\hline
\end{tabular}

Pri izradi tablica prednost se davala izvještajima kao izvoru podataka ispred samih publikacija iz nekoliko razloga. U publikacijama su se ponekad navodili članovi prethodnih uredničkih odbora i prethodni glavni urednici, u pravilu ako su te publikacije pripremljene za vrijeme prethodnog uredničkog odbora (ali su objavljene tek u idućoj kalendarskoj godini, kada je urednički odbor već bio u drugom sastavu). U nekim su se zbornicima sa skupova kao urednički odbori navodili članovi programskog odbora skupa umjesto članova uredničkog odbora niza u kojem je zbornik objavljen. Za niz Posebna izdanja HKD-a (tablica 3) ne postoje podaci za godine 2003. i 2004. budući da taj niz nije spominjan u izvješćima, a nemoguće je preuzeti podatke s publikacija jer navedenih godina u tome nizu nije objavljena nijedna publikacija.

Podaci o uredničkim odborima i glavnim urednicima za publikacije koje su objavljene izvan nizova nisu navedeni. Na publikacijama izvan nizova navođeni su urednički odbori i glavni urednici nekog od nizova, a neke publikacije objavljene izvan nizova objavljene su u suizdavaštvu i imale su urednički odbor drugog izdavača. Postoje i publikacije objavljene izvan nizova u kojima nisu objavljena imena glavnog urednika i članova uredničkih odbora. 


\section{Sadržajno profiliranje nizova}

\section{Izdanja HKD-a}

Današnji niz Izdanja HKD-a ujedno je i najstariji niz za koji je zatražena ISSN-oznaka, i to prije nego što je 1992. godine utemeljen hrvatski Ured za ISSN. Oznaka niza Izdanja Hrvatskoga bibliotekarskog društva je ISSN 0419-9278. Novom promjenom naziva društva ponovo se mijenja naslov niza, pa on 1998. godine postaje Izdanja Hrvatskoga knjižničarskog društva s oznakom ISSN 1846-5544. Numeracija publikacija kontinuirana je od 1968. godine, bez obzira na promjene naslova niza.

U nizu je do kraja 2016. godine objavljeno 65 publikacija. Posebno je interesantno pratiti profiliranje niza. Nakon pokretanja 1968. godine u prvom skupštinskom izvještaju stoji da je, prema zamisli A. Stipčevića, namjera da se ,u toj zbirci tiskaju djela s područja povijesti hrvatske knjige i hrvatskih biblioteka i knjige važne za unapređenje struke. “40 Do 1991. godine u nizu se zaista i objavljuju uglavnom jednoautorske stručne ili znanstvene knjige (takvih je bilo 20 od 25 objavljenih knjiga do 1991. godine, primjerice Dahlova Povijest knjige od antike do danas ili Diringerova Povijest pisma). Slijedi sedmogodišnja stanka u objavljivanju u ovome nizu (do 1998.), nakon čega se u nizu objavljuju isključivo zbornici s raznih skupova, ponajviše sa Seminara Arhivi, knjižnice, muzeji, Okrugloga stola o slobodnom pristupu informacijama, Dana specijalnih i visokoškolskih knjižnica i još ponekih. Postoje neke specifičnosti pojedinih zbornika. Primjerice zbornik Seminara Arhivi, knjižnice, muzeji ne izlazi svake godine u izdanju HKD-a. Zbornik Dana specijalnih i visokoškolskih knjižnica (skup se ranije zvao Dani specijalnog knjižničarstva Hrvatske) izlazio je najprije izvan nizova (dva zbornika s radovima s prva tri održana skupa). Zbornik Okruglog stola o slobodnom pristupu informacijama izlazi od početka (2001. godine) u nizu Izdanja HKD-a, a od 2014. godine (zbornik s 13. i 14. okruglog stola) ima vlastitu ISSN-oznaku (ključni naslov Slobodan pristup informacijama) i od te je godine uključen u bazu EBSCO.

Iako je početna ideja iz 1968. godine bila drugačija, niz Izdanja Hrvatskoga knjižničarskog društva već gotovo dva desetljeća objavljuje isključivo zbornike sa znanstvenih i stručnih skupova - zbornici se ne objavljuju ni u jednom drugom nizu HKD-a.

\section{Posebna izdanja HKD-a}

U nizu koji danas ima naslov Posebna izdanja Hrvatskoga knjižničarskog društva objavljeno je 14 publikacija, prva 1968., a zadnja 2009. godine. Prvi naslov niza bio je Posebna izdanja Društva bibliotekara Hrvatske, zatim Posebna izdanja Hrvatskog bibliotekarskog društva (naziv društva promijenjen je 1971., a prva knjiga u nizu objavljena je 1975.), a prva knjiga pod današnjim naslovom niza

40 Mišić, Jelka. Društvo. Nav. dj. Str. 31. 
objavljena je 2000. godine. Nizu nije dodijeljena ISSN-oznaka ni za jednu verziju naslova niza.

Osim Veroninog Pravilnika i priručnika za izdradbu abecednih kataloga (dva izdanja i pretisak), u nizu su objavljene još tri knjige hrvatskih autora, dva prijevoda knjiga stranih autora i četiri uredničke knjige.

\section{Povremena izdanja HKD-a}

Godine 1978. pokrenut je niz Povremena izdanja Hrvatskoga bibliotekarskog društva. U izvještaju o radu Društva u vrijeme pokretanja niza ne spominje se posebno taj niz, ali piše: „U cilju da što prije omogući primjenu pojedinih međunarodnih standarda za bibliografski opis Društvo je među prvima u svijetu prevelo i objavilo u svojim izdanjima neke od standarda. ${ }^{“ 41}$ Pod tim naslovom niza objavljeno je 10 knjiga, do 1993. godine, a nakon što je objavljena zadnja knjiga, nizu je dodijeljena oznaka ISSN 1334-7896. Godine 1995. pokreće se kolo Novi niz u nizu Povremena izdanja Hrvatskoga bibliotekarskog društva s oznakom ISSN 1334-7675 i pod tim naslovom kola i niza objavljena je jedna knjiga. Pod promijenjenim naslovom niza (Povremena izdanja Hrvatskoga knjižničarskog društva) u kolu Novi niz objavljuju se knjige od 1999. godine. Oznaka kola je ISSN 13347667.

Novi niz je kao kolo unutar niza Povremena izdanja Hrvatskoga bibliotekarskog društva pokrenut kako bi se „novim formatom i novim uvezom (tvrdim) slijedila vrsnoća IFLA-inih izdanja“". ${ }^{42}$ Zanimljivo je da je u tvrdom uvezu objavljena samo prva knjiga u kolu. Novi niz, kako se i iz njegova naziva može zaključiti, započinje novom numeracijom knjiga (od knjige 1 za 1995. godinu). Nakon pokretanja kola Novi niz, objavljena je još jedna publikacija u nizu Povremena izdanja Hrvatskoga knjižničarskog društva, izvan kola Novi niz (knjiga br. 11 godine 2003.). Nizu s tom verzijom naslova nije dodijeljena ISSN-oznaka. Nakon toga izvan kola Novi niz više nisu objavljivane publikacije, pa je ono zapravo postalo sadržajnim sljedbenikom „staroga“ niza - iako je numeracija započela ispočetka, sve publikacije u Novom nizu (kao i sve prethodno objavljene publikacije u nizu Povremena izdanja) prijevodi su naslova IFLA-inih nizova IFLA Series on Bibliographic Control, IFLA Professional Reports i IFLA Publication Series. ${ }^{43}$ Taj je niz od početka vrlo jasno definiran i tematski određen i bez izuzetka objavljuje samo onu vrstu publikacija zbog koje je i začet - sve publikacije u nizu i u kolu Novi niz prijevodi su IFLA-inih publikacija.

\footnotetext{
41 Izvještaj o radu Hrvatskoga bibliotekarskog društva između XXI. i XXII. redovne skupštine. // Vjesnik bibliotekara Hrvatske 24, 1/4(1979-1980), str. 238-239.

42 Nebesny, Tatjana. Nav. dj. Str. 97.

43 Barbarić, Ana. Prijevodi. Nav. dj.
} 
Od pokretanja niza Povremena izdanja Hrvatskoga bibliotekarskog društva 1978. godine pa do kraja 2016. godine u nizu su objavljene ukupno 43 knjige (11 u nizu i 32 u kolu niza).

\section{Elektronička izdanja HKD-a}

Niz Elektronička izdanja HKD-a pokrenut je 2007. godine i do 2013. je u njemu objavljeno šest publikacija. Prema izvještaju o radu iz 2008. godine, niz je pokrenut ,s ciljem da se u ovom nizu objavljuju naslovi koje će Društvo izdavati samo u elektroničkoj verziji. Tematski ni opsegom niz nije ograničen određenim stručnim područjem. Potrebno je osnovati uredništvo i izabrati glavnog urednika." "44 Unatoč takvu početnom planu, u praksi su za sada (do kraja 2016.) publikacije sadržajno bliske onima u Novom nizu Povremenih izdanja HKD-a - objavljuju se prijevodi IFLA-inih publikacija. Medij je (a time i način pristupa) jedina razlika između ta dva niza. Oznaka niza je ISSN 1846-5447.

\section{Hrvatsko knjižničarstvo}

Niz Hrvatsko knjižničarstvo pokrenut je 2011. godine s ciljem da objavljuje znanstvene knjige hrvatskih knjižničara koje su od posebnog znanstvenog i kulturnog interesa za Hrvatsku. ${ }^{45}$ Taj se cilj djelomično preklapa s početnom idejom niza Izdanja Društva bibliotekara Hrvatske iz 1968. godine, ali budući da se u nizu Izdanja Hrvatskoga knjižničarskog društva danas objavljuju isključivo zbornici, niz Hrvatsko knjižničarstvo za cilj je preuzeo objavljivanje znanstvenih publikacija hrvatskih knjižničara. To bi trebali biti prerađeni doktorski ili znanstveni magistarski radovi ili potpuno novi rukopisi koji zadovoljavaju znanstvene standarde. Do kraja 2016. godine objavljena su dva naslova (2012. i 2013. godine), a oba se temelje na tekstovima obranjenih znanstvenih magistarskih radova koji su nadopunjeni, dorađeni i osuvremenjeni za potrebe objavljivanja u ovome nizu. ISSN-oznaka niza je ISSN 1848-493X.

\section{Umjesto zaključka - pitanja o budućnosti}

Iako su u ranijim poglavljima navedene poneke nedosljednosti, važno je istaknuti da je ideja o pokretanju nakladničke djelatnosti prije pola stoljeća bila izuzetno napredna i vizionarska, a knjige koje je objavio HKD značajno su utjecale na razvoj hrvatskoga knjižničarstva. HKD nije profesionalni nakladnik, već neprofitna udruga, pa je brojka od 148 knjiga zaista impresivna. Isti razlozi (neprofitnost udruge i činjenica da HKD nije profesionalni nakladnik) mogu biti opravdanje za

\footnotetext{
44 Willer, Mirna. Izvještaj o radu uredničkog odbora Izdanja Hrvatskoga knjižničarskog društva za niz Elektronička izdanja HKD-a : 2007.-2008. // Vjesnik bibliotekara Hrvatske 51, 1/4(2008), str. 231.

45 Hebrang Grgić, Ivana. Izvješće. Nav. dj.
} 
prikazane nedosljednosti - svi glavni urednici i članovi uredničkih odbora uredničke su poslove obavljali u svoje slobodno vrijeme, često uz nikakvu ili minimalnu financijsku naknadu. Opisano bi istraživanje trebalo biti temelj daljnjeg razvoja i napretka ovog izuzetno važnog segmenta djelatnosti HKD-a.

Prvo pitanje koje je nametnulo ovo istraživanje jest pitanje naziva nizova. Možemo li i dalje biti zadovoljni generičkim nazivima (izdanja, posebna izdanja, povremena izdanja...) ili bi bilo bolje naslove nizova promijeniti, tj. započeti nove nizove koji bi imali prepoznatljive i jasnije naslove? Zatim, je li moguće više publikacija objavljivati u elektroničkome obliku? Takve bi publikacije mogle biti besplatno dostupne na stranicama HKD-a i tada se ne bi mogle prodavati, no smanjio bi se trošak tiska i distribucije, a radovi (npr. u zbornicima) bi postali vidljiviji i citiraniji, što bi bilo korisno za cijelu knjižničarsku zajednicu. Što bi se u tom slučaju dogodilo s nizom Elektronička izdanja HKD-a? Bi li sve elektroničke publikacije morale biti objavljene u tom nizu ili bi ipak mogle biti objavljene u nizovima kojima sadržajno pripadaju?

Je li moguće publikacije koje su objavljene u tiskanom obliku nakon određenog vremena učiniti dostupnima u elektroničkome obliku? Godine 2009. A. Barbarić predložila je da se sva izdanja nakon godine dana stave u elektronički oblik. ${ }^{46}$ Takav postupak ne bi trebao biti prezahtjevan jer izdavač ima konačnu verziju prijeloma koji je išao u tisak. Na taj bi se način neprodani tiskani primjerci mogli otpisati, a tekstovi bi bili vidljiviji i imali veći utjecaj na širu knjižničarsku zajednicu.

Je li moguće financijski olakšati rad uredništvima i HKD-u uvođenjem izvršnih, tehničkih i grafičkih urednika (kako je predloženo 2011. godine ${ }^{47}$ )?

Što će biti s Pravilnikom o nakladničkoj djelatnosti? On u ovom radu nije detaljnije analiziran jer je u planu njegova promjena, koja je nužna, ali tek nakon usuglašavanja cjelokupne nakladničke politike HKD-a.

Mogu li se u nakladničku politiku HKD-a implementirati odluke koje će povećati produkciju? Produkcija bilježi zabrinjavajući pad posljednjih godina i to bi svakako trebalo promijeniti. Možda nije potrebno da produkcija naraste na onu iz „,najboljih“ godina ( 9 u 2004. ili 10 u 2007.), no trebalo bi zadržati ritam objavljivanja barem triju knjiga godišnje (što je prosjek u 50 godina objavljivanja).

Može li se nešto učiniti kako bi se povećala prodaja? Je li dovoljno oglašavanje na stranicama HKD-a? Ranija su istraživanja pokazala da prodaja i nije tako loša - u prve se dvije godine nakon objavljivanja proda oko $80 \%$ naklada, a tek kasnije prodaja naglo pada. Treba imati na umu da su knjige objavljene u izdanju HKD-a

46 Hrvatsko knjižničarsko društvo. Zapisnik s 5. sjednice Glavnog odbora 13. studenoga 2009. [citirano: 2016-10-28]. Dostupno na http://hkdrustvo.hr/datoteke/743.

47 Hrvatsko knjižničarsko društvo. Zapisnik sa 7. sjednice Glavnog odbora HKD-a 17. lipnja 2011. [citirano: 2016-10-28]. Dostupno na http://hkdrustvo.hr/datoteke/1228. 
izuzetno važne za obrazovanje knjižničara jer su na popisima literature za sve razine studija, za stručne ispite, a često se koriste i kao izvori za diplomske radove. ${ }^{48}$ Ako HKD smanji produkciju, tu će literaturu početi objavljivati drugi izdavači jer potreba postoji (taj trend već se može naslutiti). Je li to u interesu HKD-a?

To su samo neka od praktičnih pitanja na koja treba odgovoriti jer se nakladništvo HKD-a nalazi na prekretnici.

Nakladnička je djelatnost HKD-a izuzetno važna i vrijedna te svakako treba temeljito razmisliti o strategiji njezina razvoja i budućnosti koja bi se trebala temeljiti na raščišćenim nedoumicama vezanim uz terminologiju, sadržajno određenje nizova i učestalost objavljivanja.

\section{LITERATURA}

AKM časopis [citirano: 2016-12-11]. Dostupno na http://hrcak.srce.hr/ojs/index.php/ $\mathrm{akm} / \mathrm{index}$

Barbarić, Ana. Izvještaj o radu uredničkog odbora Izdanja Hrvatskoga knjižničarskog društva za niz Povremena izdanja HKD-a. Novi niz : rujan 2008. - rujan 2010. // Vjesnik bibliotekara Hrvatske 53, 3/4(2010), str. 222.

Barbarić, Ana. Prijevodi IFLA-inih dokumenata u izdanju Hrvatskoga knjižničarskog društva : analiza, stanje, perspektiva. // Libellarium 7, 2(2014), str. 197-230.

Gjurković Govorčin, Rajka. Izvještaj o radu uredničkog odbora Izdanja Hrvatskoga knjižničarskog društva za niz Izdanja HKD-a : 2002.-2004. // Vjesnik bibliotekara Hrvatske. 47, 3/4(2004), str. 159.

Gomerčić, Nada. Izvještaj glavnog urednika Društvenih izdanja Hrvatskoga bibliotekarskog društva. // Vjesnik bibliotekara Hrvatske 32, 1/4(1989), str. 193.

Gomerčić, Nada. Izvještaj uredničkog odbora društvenih izdanja. // Vjesnik bibliotekara Hrvatske 30, 1/4(1987), str. 190.

Hebrang Grgić, Ivana. Izvješće glavne urednice niza Hrvatsko knjižničarstvo Hrvatskoga knjižničarskog društva. // Vjesnik bibliotekara Hrvatske 56, 1/2(2013), str. 349-350.

Hebrang Grgić, Ivana. Uloga nakladničke djelatnosti Hrvatskoga knjižničarskog društva u obrazovanju knjižničara. // Vjesnik bibliotekara Hrvatske 58, 1/2(2015), str. 263-276.

48 Hebrang Grgić, Ivana. Uloga nakladničke djelatnosti Hrvatskoga knjižničarskog društva u obrazovanju knjižničara. // Vjesnik bibliotekara Hrvatske 58, 1/2(2015), str. 263-276. 
Hrvatsko knjižničarsko društvo. Društvena izdanja : narudžba [citirano: 2016-10-28]. Dostupno na http://hkdrustvo.hr/izdanja/drustvena

Hrvatsko knjižničarsko društvo. Društvena izdanja [citirano: 2016-10-28]. Dostupno na http://hkdrustvo.hr/hr/izdanja/kategorija/drustvena/

Hrvatsko knjižničarsko društvo. O nama : organizacija [citirano: 2016-10-10]. Dostupno na http://hkdrustvo.hr/hr/o_nama/

Hrvatsko knjižničarsko društvo. Statut. 2015. [citirano: 2016-10-29]. Dostupno na http://hkdrustvo.hr/hr/statut/

Hrvatsko knjižničarsko društvo. Zapisnik s 11. sjednice Glavnog odbora HKD-a održane 19. lipnja 2006. [citirano: 2016-10-28]. Dostupno na http://hkdrustvo.hr/ datoteke/210

Hrvatsko knjižničarsko društvo. Zapisnik s 2. sjednice Glavnog odbora Hrvatskoga knjižničarskog društva održane 15. prosinca 2006. [citirano: 2016-11-02]. Dostupno na http://hkdrustvo.hr/datoteke/259

Hrvatsko knjižničarsko društvo. Zapisnik s 5. sjednice Glavnog odbora 13. studenoga 2009. [citirano: 2016-10-28]. Dostupno na http://hkdrustvo.hr/datoteke/743

Hrvatsko knjižničarsko društvo. Zapisnik sa 4. sjednice Glavnog odbora HKD-a održane 24. siječnja 2003. [citirano: 2016-11-02]. Dostupno na http://hkdrustvo.hr/datoteke/23

Hrvatsko knjižničarsko društvo. Zapisnik sa 6. sjednice Glavnog odbora HKD-a održane 19. prosinca 2005. [citirano: 2016-10-28]. Dostupno na http://hkdrustvo.hr/ datoteke/155

Hrvatsko knjižničarsko društvo. Zapisnik sa 6., elektroničke sjednice Glavnog odbora HKD-a. 3. i 4. svibnja 2011. [citirano: 2016-10-28]. Dostupno na http://hkdrustvo. $\mathrm{hr} / \mathrm{hr} /$ dokumenti/kategorija/zapisnici_glavnog_odbora_2010/

Hrvatsko knjižničarsko društvo. Zapisnik sa 7. sjednice Glavnog odbora HKD-a 17. lipnja 2011. [citirano: 2016-10-28]. Dostupno na http://hkdrustvo.hr/datoteke/1228

Izvještaj o radu Hrvatskoga bibliotekarskog društva između XXI. i XXII. redovne skupštine. // Vjesnik bibliotekara Hrvatske 24, 1/4(1979-1980), str. 238-239.

Mišić, Jelka. Društvo bibliotekara Hrvatske od svibnja 1967. do svibnja 1969. : (prema tajničkom izvještaju podnesenom XVII. godišnjoj skupštini). // Vjesnik bibliotekara Hrvatske 1/2(1969), str. 31.

Mišić, Jelka. O izdavačkoj djelatnosti Društva bibliotekara Hrvatske. // Vjesnik bibliotekara Hrvatske 3/4(1968), str. 252-255.

Nebesny, Tatjana. Bibliografija izdanja Hrvatskoga knjižničarskog društva : 1940. -2000. // Hrvatsko knjižničarsko društvo : 14. III. 1940. - 14. III. 2000. : spomenica / uredile Živković, Daniela ; Horvat, Aleksandra ; Malnar, Aleksandra. Zagreb : Hrvatsko knjižničarsko društvo, 2000. Str. 41-55. 
Nebesny, Tatjana. Izvještaj o radu uredničkog odbora izdanja HBD-a : 1994.-1996. // Vjesnik bibliotekara Hrvatske 39, 3/4(1996), str. 97.

Nebesny, Tatjana. Izvještaj uredništva Društvenih izdanja. // Vjesnik bibliotekara Hrvatske 37, 3/4(1994), str. 147.

Statut Hrvatskoga bibliotekarskog društva. // Vjesnik bibliotekara Hrvatske 29, 1/4(1986), str. 183-195.

Statut Hrvatskoga bibliotekarskog društva. // Vjesnik bibliotekara Hrvatske 35, 3/4(1992), str. 237-250.

Statut Hrvatskoga knjižničarskog društva. // Vjesnik bibliotekara Hrvatske 42, 1/4(1999), str. 179-166.

Statut Hrvatskoga knjižničarskog društva. // Vjesnik bibliotekara Hrvatske 45, 3/4(2002), str. 307-321.

Stipčević, Aleksandar. Izvještaj Uredništva društvenih izdanja od 1975. do 1977. godine. // Vjesnik bibliotekara Hrvatske 23, 1/4(1977/78), str. 111.

Špiranec, Sonja (i. e. Špac, Vesna). Izvještaj glavne urednice niza Izdanja Hrvatskoga knjižničarskog društva. // Vjesnik bibliotekara Hrvatske 58, 1/2(2015), str. 404-406.

Wiler, Mirna. Izvještaj o radu uredničkog odbora Izdanja Hrvatskoga knjižničarskog društva za niz Povremena izdanja HKD-a : 2003.-2004. // Vjesnik bibliotekara Hrvatske 47, 3/4(2004), str. 162-166.

Willer, Mirna. Izvještaj o radu uredničkog odbora Izdanja Hrvatskog knjižničarskog društva za niz Povremena izdanja HKD-a. Novi niz : 2006.-2008. // Vjesnik bibliotekara Hrvatske 51, 1/4(2008), str. 229-230.

Willer, Mirna. Izvještaj o radu uredničkog odbora Izdanja Hrvatskoga knjižničarskog društva za niz Elektronička izdanja HKD-a : 2007.-2008. // Vjesnik bibliotekara Hrvatske 51, 1/4(2008), str. 231. 